Research Article

\title{
Effect of Melt Temperature on the Effectiveness of the Grain Refining in Al-Si Castings
}

\author{
A. M. Samuel, ${ }^{1}$ S. S. Mohamed, ${ }^{1}$ H. W. Doty, ${ }^{2}$ S. Valtierra, ${ }^{3}$ and F. H. Samuel $\mathbb{D}^{1}$ \\ ${ }^{1}$ Département des Sciences Appliquées, Université du Québec à Chicoutimi, Saguenay, QC, Canada \\ ${ }^{2}$ General Motors Materials Engineering, 823 Joslyn Ave., Pontiac, MI 48340, USA \\ ${ }^{3}$ Nemak, S.A., P.O. Box 100, 66221 Garza Garcia, NL, Mexico \\ Correspondence should be addressed to F. H. Samuel; fhsamuel@uqac.ca
}

Received 27 November 2017; Accepted 20 March 2018; Published 30 May 2018

Academic Editor: Laszlo Toth

Copyright (C) 2018 A. M. Samuel et al. This is an open access article distributed under the Creative Commons Attribution License, which permits unrestricted use, distribution, and reproduction in any medium, provided the original work is properly cited.

The results inferred from the present work show that $\mathrm{Al}_{3} \mathrm{Ti}$ phase has a strong affinity to react with silicon ( $\mathrm{Si}$ ) in the molten alloy leading to formation of $(\mathrm{Al}, \mathrm{Si})_{3} \mathrm{Ti}$ phase instead. This reaction is independent of the grain refiner type. The molten liquid temperature would change its morphology from platelets at $750^{\circ} \mathrm{C}$ into dendritic structure at $950^{\circ} \mathrm{C}$. It has also been observed that $(\mathrm{Al}, \mathrm{Si})_{3} \mathrm{Ti}$ phase platelets precipitate within the $\alpha$-aluminum dendrites, whereas $\mathrm{TiB}_{2}$ or $\mathrm{AlB}_{2}$ particles are released into the surrounding interdendritic regions. Introduction of the grain refiner, regardless its type, would cause change in the $\alpha$-aluminum dendrite morphology from an elongated to a more rounded form. The results also reveal that addition of $100 \mathrm{ppm} \mathrm{B}$ will reduce the initial grain size by $\sim 85 \%$ which is more than the effect of addition of $0.2 \% \mathrm{Ti}$ in the form of Al-10\%Ti (about $65 \%$ ). Elimination of undercooling is important to obtain the maximum grain refining effect.

\section{Introduction}

Many theories have been proposed to explain the mechanism of grain refining. Two among them are the nucleation and phase diagram theories. The nucleation theory is mainly based on the presence of borides in the added grain refiner master alloy (e.g., $\mathrm{TiB}_{2}, \mathrm{AlB}_{2}$, and $\left.(\mathrm{Al}, \mathrm{Ti}) \mathrm{B}_{2}\right)$. The phase diagram theory (Figure 1) is based on the presence of pro-peritectic $\mathrm{TiAl}_{3}$ phase particles [1-3]. When a master alloy containing Al-Ti-B is added to molten metal such that the amount of Ti is less than $0.15 \%$, often boron particles are found at the centers of the grains, with dendrites enriched in titanium growing outside of the grains. In the case of the use of master alloys, AlB particles have been observed to be released towards the grain boundaries, whereas $\mathrm{Al}_{3} \mathrm{Ti}$ particles are located at the centers of the grains [4]. Easton and StJohn [5] have confirmed this observation when the master alloy used does not contain Ti. In addition, release of aluminum borides towards the grain boundaries has no significant effect on the grain refining process.

From the thermodynamics point of view, the solubility of $\mathrm{Al}_{3} \mathrm{Ti}$ is independent of the presence of boron (B). The experimental data obtained by Mondolfo et al. [7], however, show that the presence of $\mathrm{B}$ would displace the peritectic reaction towards the Al-rich extremity of the $\mathrm{Al}$ - Ti phase diagram, leading to the formation of $\mathrm{TiB}_{2}$. Sigworth [8] and Bäckerud et al. [9] suggested that $\mathrm{Al}_{3} \mathrm{Ti}$ particles are more effective in terms of grain nucleation than $\mathrm{TiB}_{2}$ phase particles. The authors proposed a hypothesis to explain why the presence of borides would slow down the dissolution rate of $\mathrm{Al}_{3} \mathrm{Ti}$ when the $\mathrm{Al}-\mathrm{Ti}-\mathrm{B}$ master alloy is added to liquid aluminum. According to $[8,9]$, borides would form layers around the aluminide particles resulting in slowing their effectiveness.

Davies et al. [10] and Maxwell and Hellawell [11] observed the presence of $\mathrm{Al}_{3} \mathrm{Ti}$ particles within the $\alpha$ - $\mathrm{Al}$ dendrites. The solidification curves obtained by Arnberg et al. [12] revealed the absence of undercooling indicating that the nucleation of grains took place by the peritectic reaction at temperatures higher than the melting temperature of aluminum. Crossley and Mondolfo [13] suggested that the reported improvement of Al-Ti-B master alloy as a grain refiner may be interpreted in terms of the displacement of the peritectic reaction of $0.15 \%$ Ti towards the extremity of the aluminum diagram leading to thermodynamically stable $\mathrm{Al}_{3} \mathrm{Ti}$ nucleating sites at low 


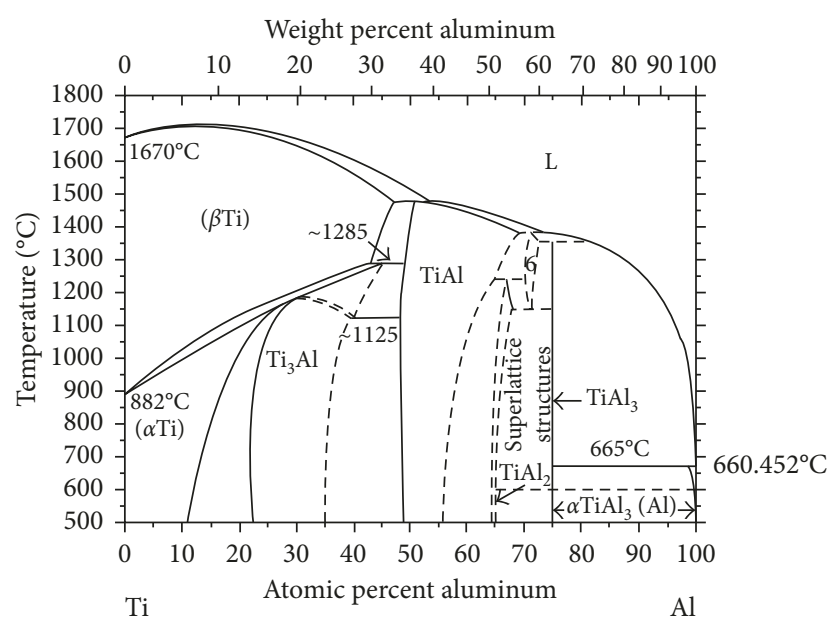

(a)

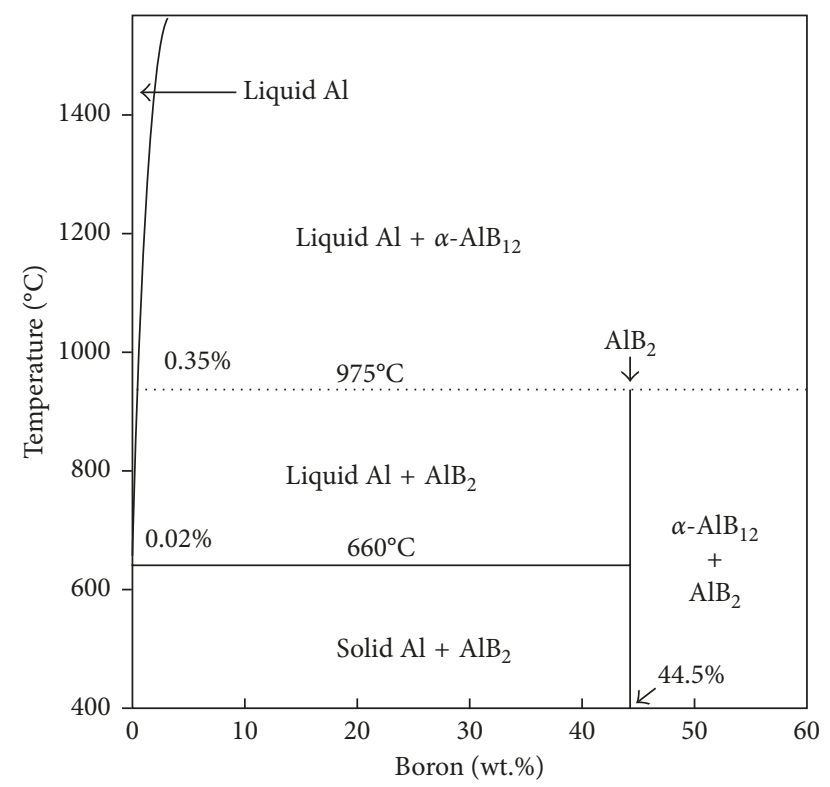

(b)

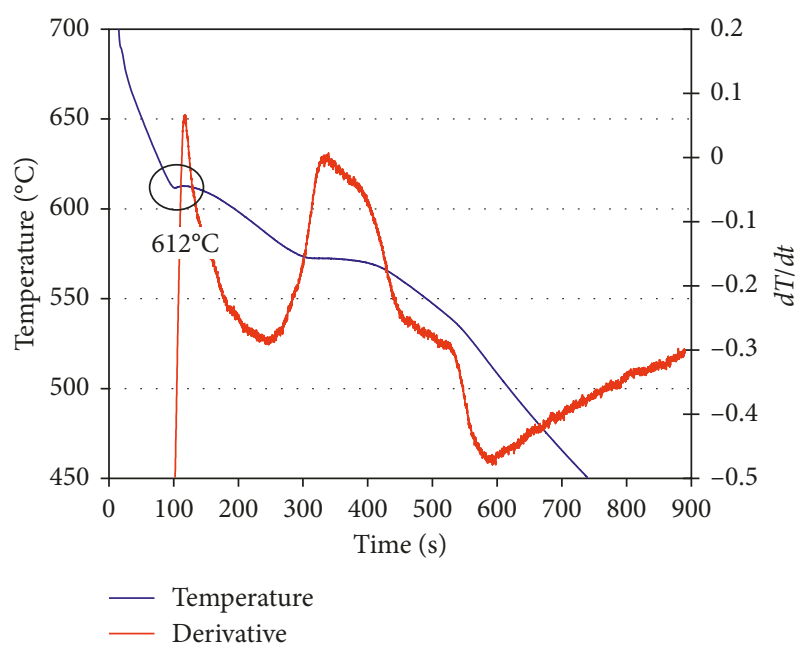

(c)

Figure 1: (a) Al-Ti phase diagram [3]. (b) Aluminum-rich corner of the Al-B phase diagram [6]. (c) Temperature-time curve obtained from the A356.2 alloy (untreated). addition, for example, $0.02 \%$. This proposition, however, is incompatible with the Al-Ti-B phase diagram [14, 15].

Mohanty et al. [16-19] injected synthetic $\mathrm{TiB}_{2}$ particles (about $5 \mu \mathrm{m}$ in diameter) into liquid aluminum along with different amounts of $\mathrm{Ti}$. In the absence of excess of $\mathrm{Ti}$, the effectiveness of $\mathrm{TiB}_{2}$ particles for grain refining was poor, and $\mathrm{TiB}_{2}$ particles were observed at the grain boundaries. Increasing the concentration of Ti resulted in improving the grain refining effectiveness of the borides, and the boride particles were observed at the center of the solidified grains. At Ti concentration higher than the peritectic concentration, layers of $\mathrm{Al}_{3} \mathrm{Ti}$ were formed on the surfaces of the $\mathrm{TiB}_{2}$ particles where layers of $\alpha$-Al were precipitated.

Jones and Pearson [20] have proposed the concept of hypernucleation at the $\mathrm{TiB}_{2}$ /liquid metal interface. According to the authors, the addition of excess of Ti causes segregation of $\mathrm{Ti}$ atoms at the $\mathrm{TiB}_{2}$ /liquid metal interface leading to the formation of a stable layer on the surface of the $\mathrm{TiB}_{2}$ particles. These layers were proven to stay stable at temperatures below the fusion temperature of aluminum. The work of Schumacher and Greer [21, 22] and Kearns et al. [23] shows that $\mathrm{AlB}_{2}$ particles would be considered as good nucleates in the absence of Ti. Master alloys of the type Al-B are largely used in the production of ultrapure aluminum to react with transition elements such as $\mathrm{V}, \mathrm{Cr}$, and $\mathrm{Zr}[24,25]$.

Boron is not considered as an effective grain refiner when added to pure aluminum [26]. Once $\mathrm{Si}$ is added to $\mathrm{Al}$, grain refining is activated together with a change in the $\alpha$-Al dendritic structure [27]. Two types of $\mathrm{B}$ compounds exist in the Al-B master alloys: $\mathrm{AlB}_{2}$ and $\mathrm{AlB}_{12}$ [28]. The $\mathrm{AlB}_{2}$ compound is stable at room temperature and contains $44.5 \% \mathrm{~B}$ [29]. It is inferred from the Al-B binary diagram presented in Figure 1(b) that there is a peritectic reaction at $975^{\circ} \mathrm{C}$ : $\mathrm{L}+\mathrm{AlB}_{12} \rightarrow \mathrm{AlB}_{2}$. A eutectic reaction (liquid $\rightarrow \alpha-\mathrm{Al}+\mathrm{AlB}_{2}$ ) takes place at $660^{\circ} \mathrm{C}$ making the maximum solubility of $\mathrm{B}$ in $\mathrm{Al}$ about $20 \mathrm{ppm}$, where the $\alpha$-Al grains would precipitate on the $\mathrm{AlB}_{2}$ particles. The melting points of $\mathrm{AlB}_{2}$ and $\mathrm{AlB}_{12}$ are $1665 \pm$ $50^{\circ} \mathrm{C}$ and $2163 \pm 50^{\circ} \mathrm{C}$, respectively, resulting in the formation of solid dispersoid particles in the molten liquid [6]. Fundamentally speaking, the addition of a grain refiner to the molten metal would result in the nucleation of new grains or its reaction with other elements in the molten metal to form nucleation sites.

The present study was undertaken to investigate the effect of the following:

(1) Type of the applied grain refiner, that is, Al-5\% Ti-1\% $\mathrm{B}$ and $\mathrm{Al}-4 \% \mathrm{~B}$ in comparison with $\mathrm{Al}-10 \% \mathrm{Ti}$. The latter forms a complex intermetallic with $\mathrm{Si}$, which slows down its effectiveness as a grain refiner.

(2) Effect of superheating $\left(750^{\circ} \mathrm{C}\right.$ or $\left.950^{\circ} \mathrm{C}\right)$ prior to casting.

\section{Experimental Procedure}

The composition of the A356 alloy used in this study is shown in Table 1.

Samplings from the different melts prepared were poured into a preheated $\left(600^{\circ} \mathrm{C}\right)$ cylindrical graphite mold to achieve near-equilibrium solidification conditions 
TABLe 1: Chemical composition (wt.\%) of as-received A356.2 ingot.

\begin{tabular}{lccccccccc}
\hline Ingot type & $\mathrm{Si}$ & $\mathrm{Mg}$ & $\mathrm{Fe}$ & $\mathrm{Cu}$ & $\mathrm{Mn}$ & $\mathrm{Zn}$ & $\mathrm{Ti}$ & $\mathrm{Pb}$ & $\mathrm{Al}$ \\
\hline $\mathrm{A} 356.2$ & 6.78 & 0.33 & 0.11 & 0.02 & 0.04 & 0.04 & 0.03 & 0.03 & $\mathrm{Bal}$ \\
\hline
\end{tabular}

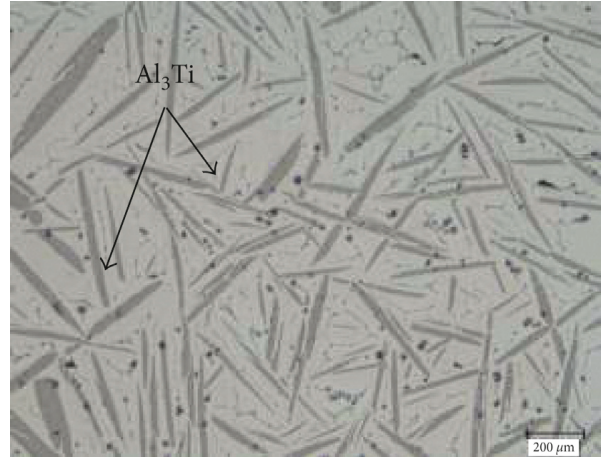

(a)

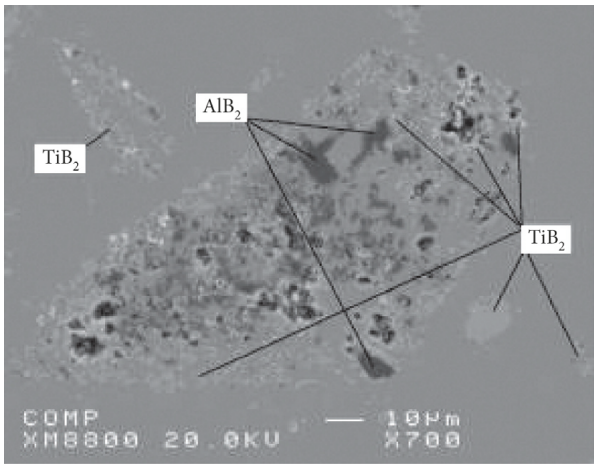

(c)

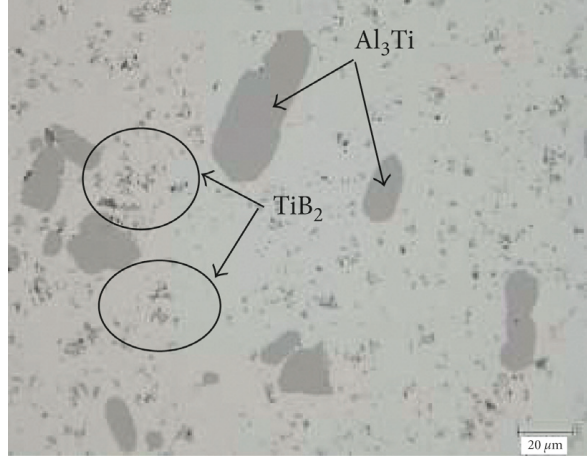

(b)

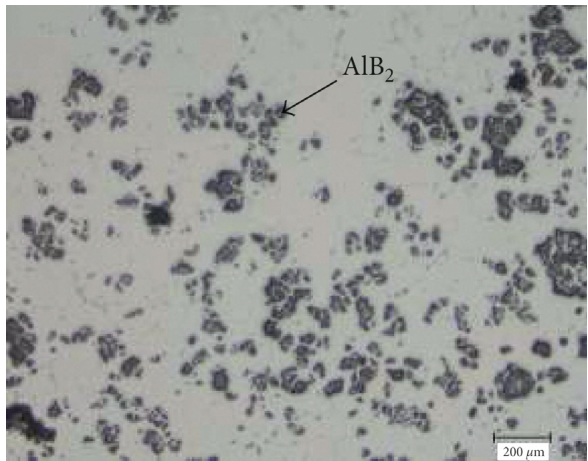

(d)

Figure 2: Optical micrographs of (a) Al-10\%Ti, (b, c) Al-5\%Ti-1\%B, and (d) Al-4\%B master alloys used in the present study.

(solidification rate $\sim 0.8^{\circ} \mathrm{C} / \mathrm{s}$ ). The grain refiner was introduced in the form of $\mathrm{Al}-10 \% \mathrm{Ti}, \mathrm{Al}-5 \% \mathrm{Ti}-1 \% \mathrm{~B}$, or $\mathrm{Al}-4 \%$ $B$ cut rods. Prior to pouring, the molten metal was mechanically stirred to prevent sedimentation of the added grain refiner at the bottom of the crucible. Prior to casting, the melt surface was skimmed to remove oxide films. The temperature-time data were obtained using a K-type (chromel-alumel) thermocouple inserted through a hole at the bottom of the graphite mold along the centerline, its tip reaching up to one-third the height of the mold from the bottom. The cooling curves were recorded using a data acquisition system attached to the thermocouple (Figure $1(c))$. Chemical analysis of all melts/castings was determined using a Spectrolab Jr CCD Spark Analyzer (average of three burns per sample).

The solidified castings were sectioned perpendicular to the centerline axis of the cylinder, at the level of the thermocouple tip, and polished for metallographic examination, using standard polishing procedures. The polished samples were examined using an optical microscope and an electron probe microanalyzer (JEOL JXA-8900L operating at $20 \mathrm{kV}$ ), equipped with energy dispersive X-ray spectroscopic (EDS) and wavelength-dispersive spectroscopic (WDS) facilities.

For measurements of the grain size, the polished samples were chemically etched using Keller's reagent (66 vol.\%
$\mathrm{HNO}_{3}, 33$ vol.\% $\mathrm{HCl}$, and 1 vol.\% $\mathrm{HF}$ ), diluted with water using a plastic bottle with a fine nozzle to slow down the etching process. Once etching was completed, the sample surfaces were rinsed, dried, and then photographed using a setup consisting of four projectors emitting red, blue, green, and yellow light. The grain sizes were measured from the digital photographs using Sigma Scan Pro 4.0 software, employing a method similar to the line intercept method.

\section{Results and Discussion}

Figure 2 shows the size and distribution of $\mathrm{Al}_{3} \mathrm{Ti}_{1}, \mathrm{TiB}_{2}$, and $\mathrm{AlB}_{2}$ in the master alloys used in the present investigation. The average $\mathrm{Al}_{3} \mathrm{Ti}$ particle length varies between 10 and $50 \mu \mathrm{m}$, whereas the average length of $\mathrm{TiB}_{2}$ is less than $1 \mu \mathrm{m}$. In order to arrive at a clearer understanding of the grain refining mechanism when $\mathrm{Al}-10 \% \mathrm{Ti}$ master alloy is used, different concentrations of $\mathrm{Ti}$, varying between 0.1 and 0.6 wt. $\%$, were added. The molten metal was poured at $750^{\circ} \mathrm{C}$ or $950^{\circ} \mathrm{C}$ (depending on the amount of added Ti). In each case, the liquid metal was held for 30,60, and 90 minutes prior to pouring. During the holding time, the liquid metal was continuously stirred using a graphite impeller. Figure 3 exhibits the variation in the nucleation temperature as a function of the added Ti content and melting conditions. 


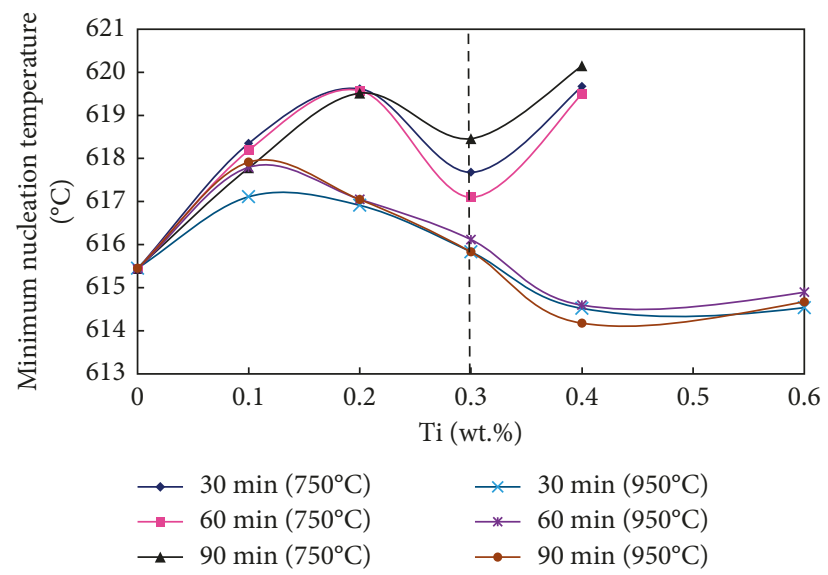

Figure 3: Variation of the nucleation temperature as a function of added Ti and melting conditions. Points above 0.6 wt.\% Ti are extrapolation.

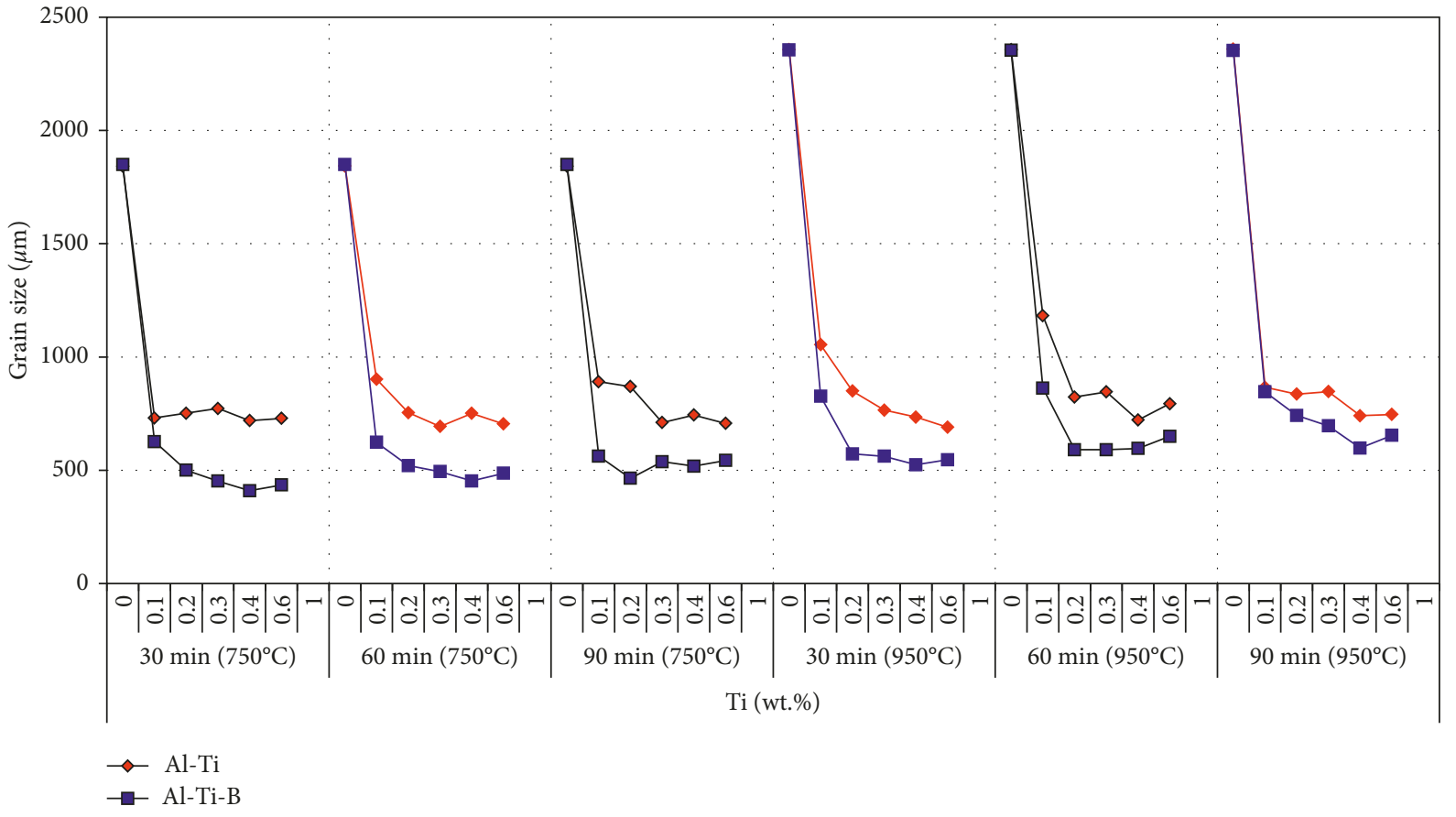

FIgURE 4: Variation in the grain size as a function of added Ti and melting conditions.

Based on this figure, the following observations may be made:

(1) The nucleation temperature is strongly influenced by the Ti concentration regardless the melting conditions. At $750^{\circ} \mathrm{C}, 0.3 \% \mathrm{Ti}$ (broken line in Figure 3 ) results in depressing the nucleation temperature regardless the holding time.

(2) At $950^{\circ} \mathrm{C}$, adding $0.1 \% \mathrm{Ti}$ produces the same effect as that observed for $0.3 \% \mathrm{Ti}$ at $750^{\circ} \mathrm{C}$. In this case, increasing the $\mathrm{Ti}$ content results in a continuous decrease in the nucleation temperature.

(3) Holding time seems to have no significant effect on the nucleation temperature. In contrast, the melting temperature separates the curves into two distinct series.
The variation in the alloy grain size as a function of $\mathrm{Ti}$ and melting conditions is illustrated in Figure 4. The initial average grain size of the as-received alloy was about $1854 \pm 20 \mu \mathrm{m}$ when the molten metal was poured at $750^{\circ} \mathrm{C}$. Although addition of $0.15-0.2 \% \mathrm{Ti}$ proved to be sufficient to reduce the grain size to approximately $600 \pm 10 \mu \mathrm{m}(\sim 70 \%)$, there was a tendency for slight increase in the grain size at the holding time of $90 \mathrm{~min}$. This increase may be interpreted in terms of either particle sedimentation or loss in the effectiveness of grain refining. These results are in good agreement with those reported by other researchers [30-32]. As mentioned previously $[1,2]$, the $\mathrm{Al}_{3}$ Ti particles have the tendency to react with $\mathrm{Si}$ from the surrounding matrix to form a complex compound, mainly ( $\mathrm{Al}, \mathrm{Si})_{3} \mathrm{Ti}$ which contains $10 \% \mathrm{Si}$, as shown in Figure 5 and Table 2. 


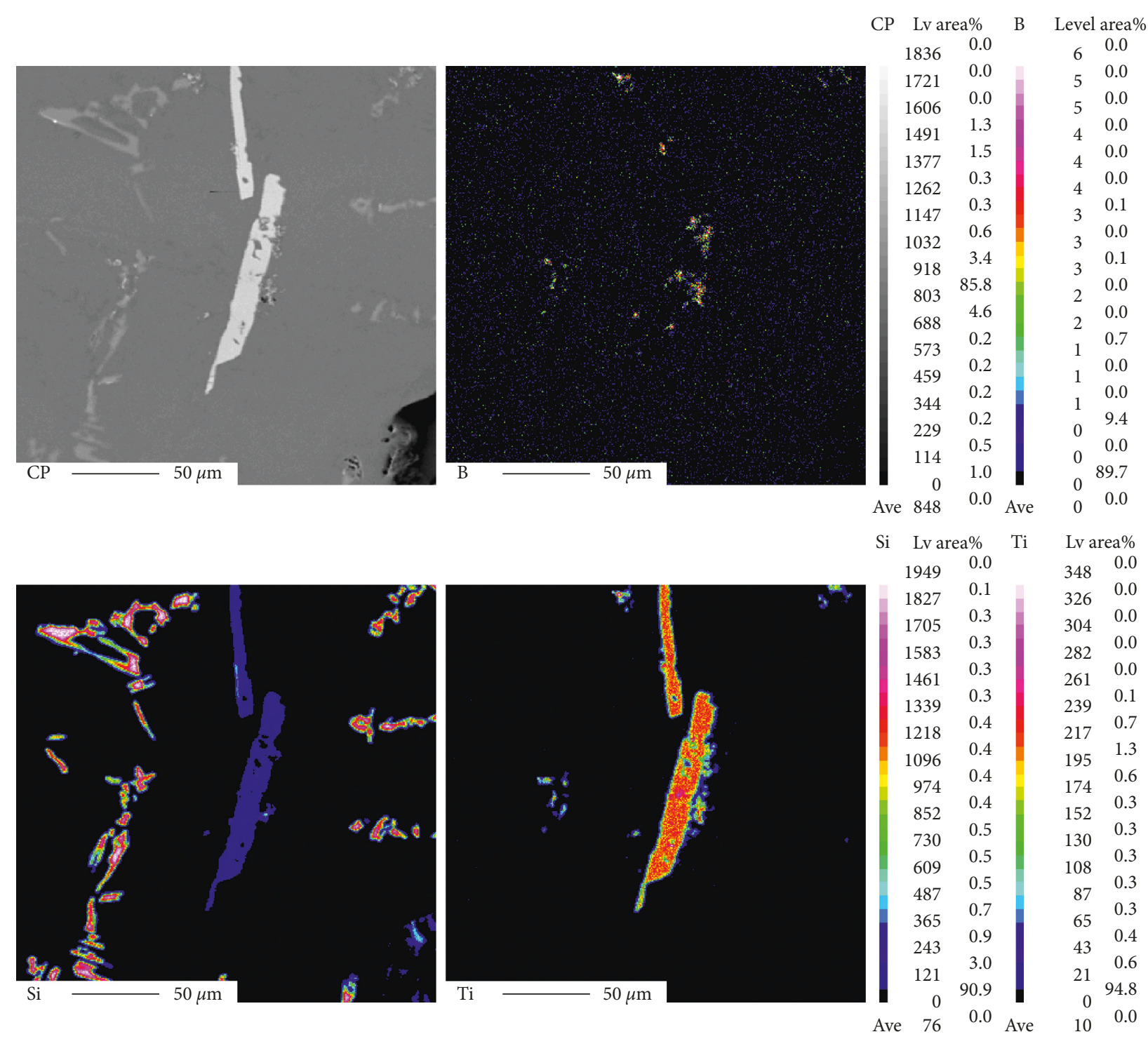

FIgURE 5: Element distribution in the $(\mathrm{Al}, \mathrm{Si})_{3} \mathrm{Ti}$ platelets.

TABLe 2: Identification of the phase rich in Ti.

\begin{tabular}{|c|c|c|c|}
\hline Points & Element & at.\% & Suggested composition \\
\hline \multirow{3}{*}{1} & $\mathrm{Al}$ & 63.895 & \multirow{3}{*}{$(\mathrm{Al}, \mathrm{Si})_{3} \mathrm{Ti}$} \\
\hline & $\mathrm{Ti}$ & 24.224 & \\
\hline & $\mathrm{Si}$ & 10.096 & \\
\hline \multirow{3}{*}{2} & $\mathrm{Al}$ & 63.935 & \multirow{3}{*}{$(\mathrm{Al}, \mathrm{Si})_{3} \mathrm{Ti}$} \\
\hline & $\mathrm{Ti}$ & 23.994 & \\
\hline & $\mathrm{Si}$ & 10.144 & \\
\hline \multirow{3}{*}{3} & $\mathrm{Al}$ & 64.300 & \multirow{3}{*}{$(\mathrm{Al}, \mathrm{Si})_{3} \mathrm{Ti}$} \\
\hline & $\mathrm{Ti}$ & 24.101 & \\
\hline & $\mathrm{Si}$ & 10.006 & \\
\hline \multirow{3}{*}{4} & $\mathrm{Al}$ & 63.969 & \multirow{3}{*}{$(\mathrm{Al}, \mathrm{Si})_{3} \mathrm{Ti}$} \\
\hline & $\mathrm{Ti}$ & 24.391 & \\
\hline & $\mathrm{Si}$ & 10.085 & \\
\hline \multirow{3}{*}{5} & $\mathrm{Al}$ & 64.762 & \multirow{3}{*}{$(\mathrm{Al}, \mathrm{Si})_{3} \mathrm{Ti}$} \\
\hline & $\mathrm{Ti}$ & 24.017 & \\
\hline & $\mathrm{Si}$ & 10.061 & \\
\hline \multirow{3}{*}{6} & $\mathrm{Al}$ & 64.762 & \multirow{3}{*}{$(\mathrm{Al}, \mathrm{Si})_{3} \mathrm{Ti}$} \\
\hline & $\mathrm{Ti}$ & 24.017 & \\
\hline & $\mathrm{Si}$ & 10.061 & \\
\hline
\end{tabular}




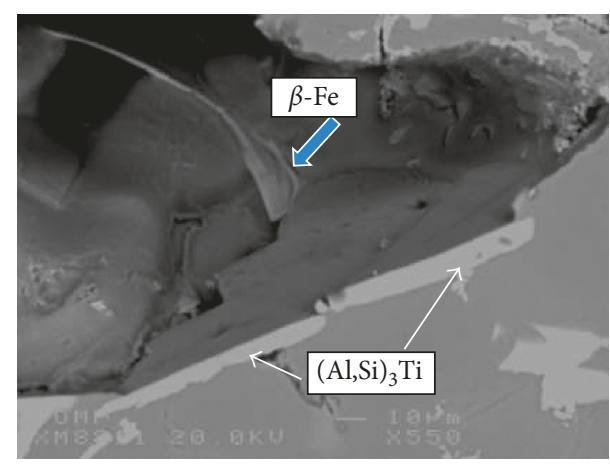

(a)

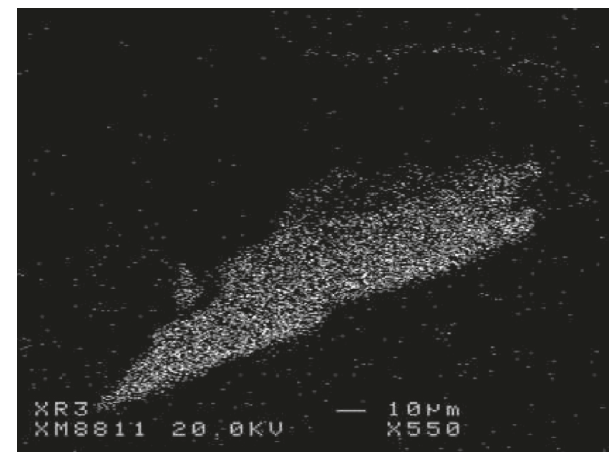

(b)

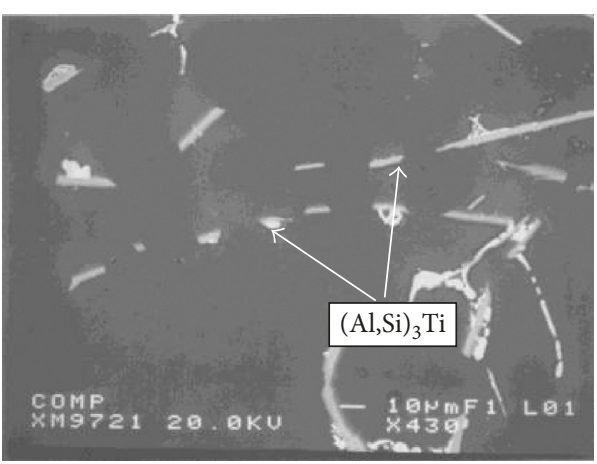

(c)

Figure 6: (a) Morphology of the new $(\mathrm{Al}, \mathrm{Si})_{3} \mathrm{Ti}$ phase particles (arrows) (melting temperature $\sim 950^{\circ} \mathrm{C}$ ); (b) Ti distribution in (a); (c) white arrows in (a) and (c) indicate possible fragmentation of the $(\mathrm{Al}, \mathrm{Si})_{3} \mathrm{Ti}$ platelets.

The morphology of $\mathrm{Al}_{3} \mathrm{Ti}$ depends on the pouring temperature: platelets $\left(750^{\circ} \mathrm{C}\right.$; Figure 5) or dendritic $\left(950^{\circ} \mathrm{C}\right.$; Figure 6). In all cases, however, the $(\mathrm{Al}, \mathrm{Si})_{3} \mathrm{Ti} / \mathrm{TiB}_{2}$ phase particles are seen to be localized within the $\alpha$-Al dendrites (Figure 7) suggesting that these particles are acting as nucleation sites.

Figure 8(a) shows that once the $\mathrm{Al}-5 \% \mathrm{Ti}-1 \% \mathrm{~B}$ master alloy is added to the liquid metal, it decomposes into $\mathrm{TiB}_{2}$ and $\mathrm{Al}_{3} \mathrm{Ti}$ particles. Due to the high density of the $\mathrm{Al}_{3} \mathrm{Ti}$ phase (approximately $3.3 \mathrm{~g} / \mathrm{cm}^{3}$ ) compared to the density of liquid aluminum at $750^{\circ} \mathrm{C}\left(\sim 2.4 \mathrm{~g} / \mathrm{cm}^{3}\right)$, some of the $\mathrm{Al}_{3} \mathrm{Ti}$ particles may tend to precipitate towards the bottom of the melting crucible or agglomerate as shown in Figure 8(b). Unlike $\mathrm{Al}_{3} \mathrm{Ti}$ particles, the $\mathrm{TiB}_{2}$ particles are precipitated

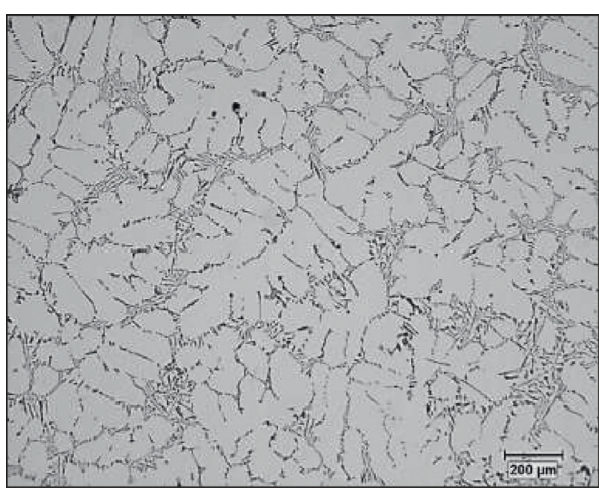

(a)

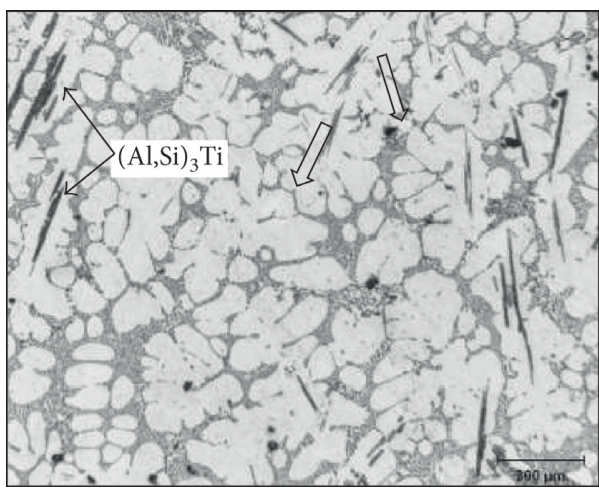

(b)

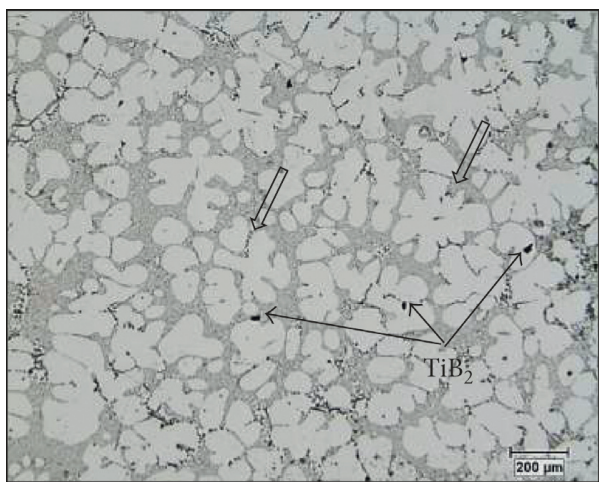

(c)

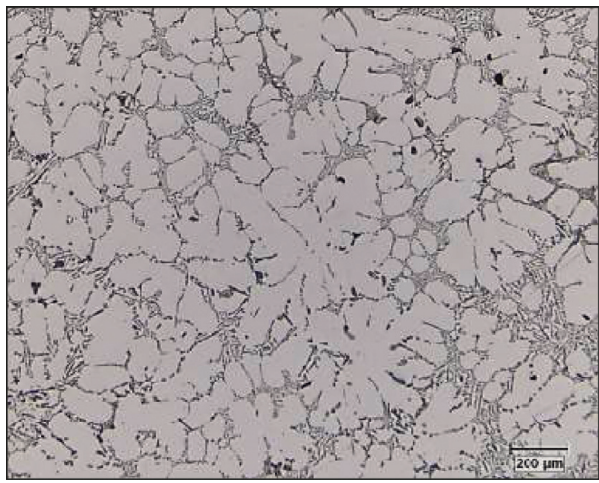

(d)

Figure 7: Morphology of $\alpha$-Al as a function of the added grain refiner: (a) no melt treatment, (b) localization of $(\mathrm{Al}, \mathrm{Si})_{3} \mathrm{Ti}$ phase particles within the $\alpha$-Al dendrites in the A356.2 alloy treated with $0.3 \% \mathrm{Ti}$ and poured at $750^{\circ} \mathrm{C}$, and (c) $0.1 \% \mathrm{Ti}, 200 \mathrm{ppm} \mathrm{B}$. Note the rosette morphology of the $\alpha$-Al dendrites (open arrows). (d) $0.1 \% \mathrm{~B}$. 


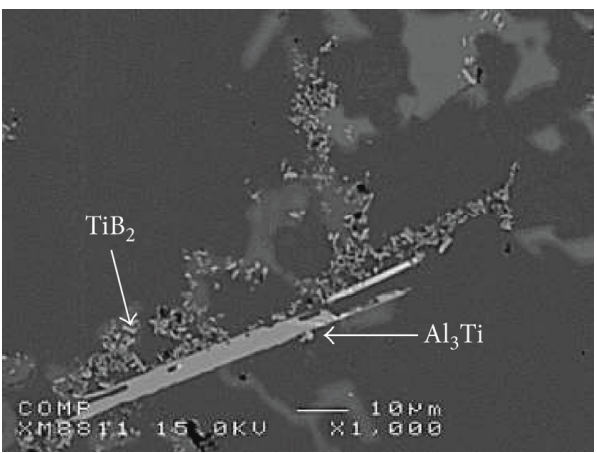

(a)

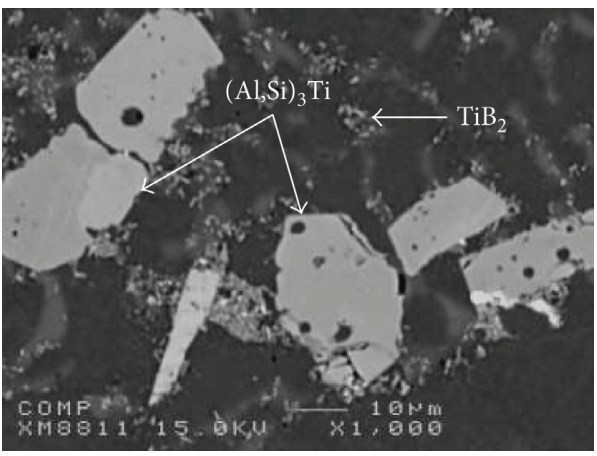

(b)

FIGURE 8: Decomposition of Al-5\%Ti-1\%B master alloy poured at $750^{\circ} \mathrm{C}$ after 60 minutes stirring: (a) $0.1 \% \mathrm{Ti}$ and (b) $0.4 \% \mathrm{Ti}$.

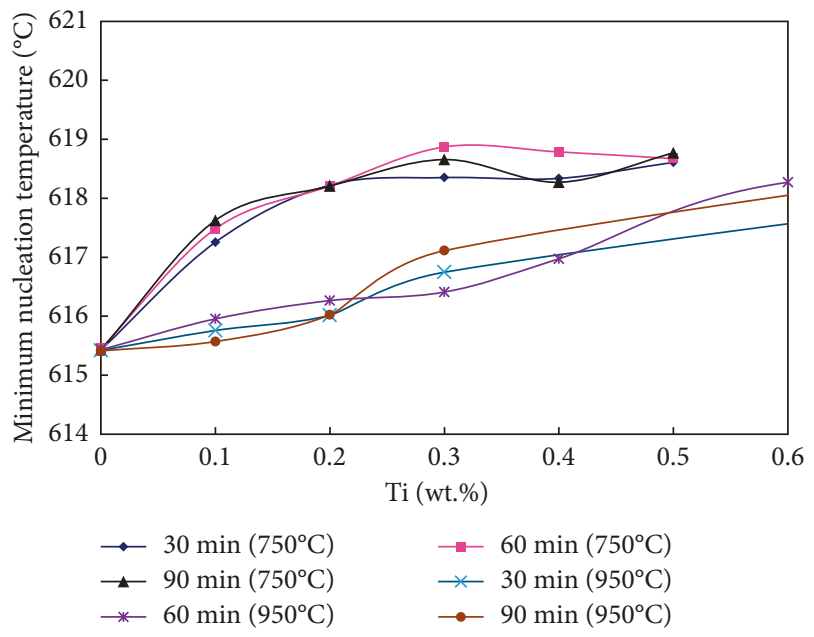

FIgURE 9: Variation in the nucleation temperature as a function of Ti content and melting conditions.

in the interdendritic regions. It is inferred from Figure 9 that, in contrast to $\mathrm{Al}_{3} \mathrm{Ti}$ addition, introduction of $\mathrm{TiB}_{2}$ particles leads to a continuous increase in the alloy nucleation temperature with the increase in the added amount of Ti. Thus, the increase in the concentration of $\mathrm{TiB}_{2}$ particles would result in the nucleation of new equiaxed grains at rates higher than their growth rates, causing grain refining at a lower level of $\mathrm{Ti}(0.1 \%)$ compared to that obtained from the addition of $\mathrm{Al}-10 \% \mathrm{Ti}$ master alloy (Figure 4).

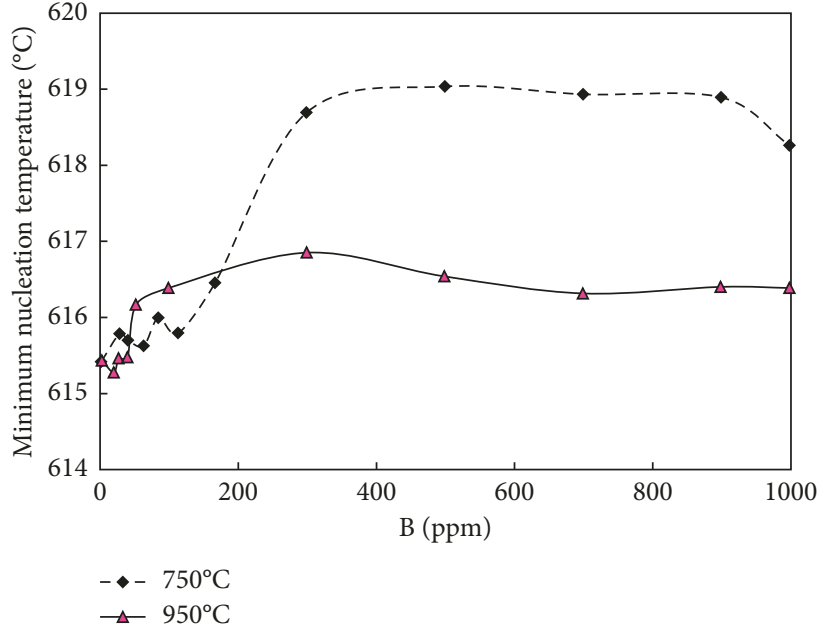

FIGURE 10: Variation of the nucleation temperature as a function of the added $\mathrm{B}$ and melting conditions.

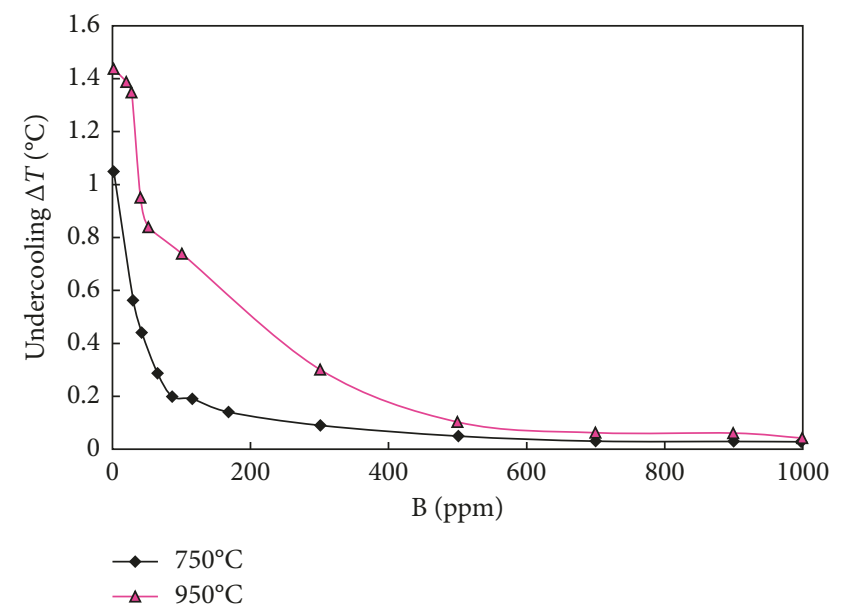

FIGURE 11: Undercooling measured in the A356.2 alloy as a function of the added $\mathrm{B}$ and pouring temperature.

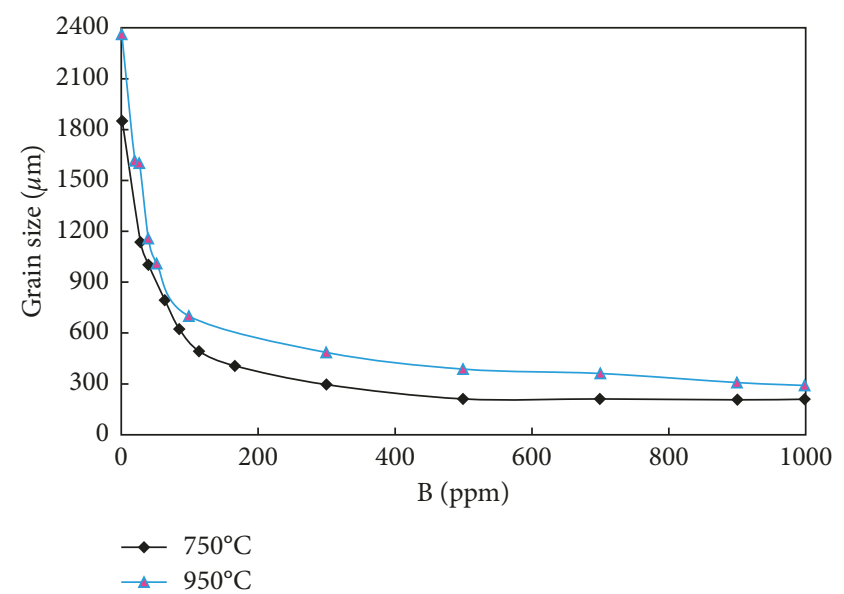

FIGURE 12: Variation of the grain size as a function of the added B and pouring temperature. 


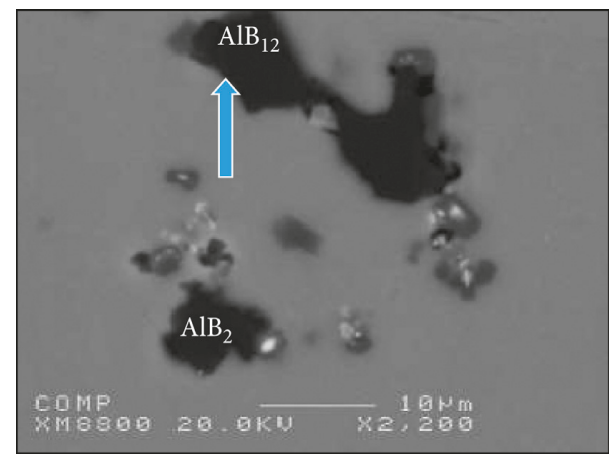

(a)

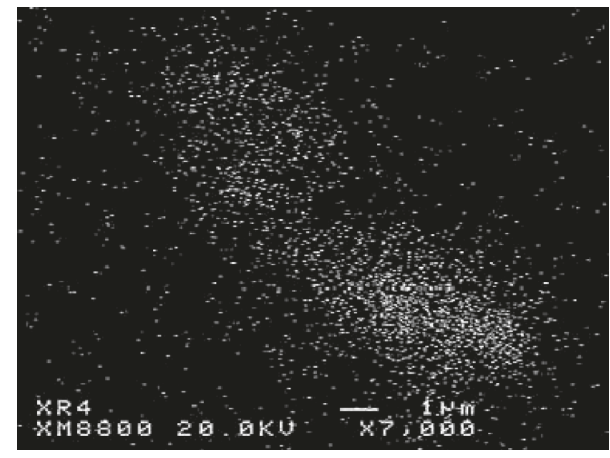

(b)

Figure 13: (a) Presence of $\mathrm{AlB}_{12}$ in ultrapure aluminum (possible decomposition of $\mathrm{AlB}_{12}$ to $\mathrm{AlB}_{2}$ ) and (b) X-ray image of $\mathrm{B}$ distribution in $\mathrm{AlB}_{12}$ phase particles in (a) (arrow).

In general, the effectiveness of a nucleating agent is determined by several factors, for example, its chemical stability, density, size, and the amount of constitutional undercooling which is a function of the alloy chemical composition. Kori et al. [33] and Nafisi and Ghomashchi [34] studied the effectiveness of $\mathrm{Al}-4 \% \mathrm{~B}$ master alloy as a grain refiner of A356 alloy. The results show that a small addition of boron shifts up the cooling curve causing the recalescence to disappear entirely. The dendritic structure transforms from a columnar to equiaxed morphology. For master alloys containing mainly $\mathrm{AlB}_{12}$ particles, it is proposed that the dissolved boron, the $\mathrm{AlB}_{2}$ particles present in the master alloy, and some transformation of $\mathrm{AlB}_{12}$ to $\mathrm{AlB}_{2}$ are responsible for the enhanced refining.

In the present study, B was added to the A356.2 alloy melts in different concentrations, as shown in Figures 10 and 11. As may be observed, the nucleation temperature increases relatively slowly compared to that seen in the case when Al-5\% Ti-1\%B master alloy was used. This observation is more clearly noted when the molten metal was poured at $950^{\circ} \mathrm{C}$. Evidence of reduction in undercooling with the increase in B concentration is observed in Figure 11. From the thermal point of view, an ideal grain refiner would remove the recalescence entirely [34-36].

Figure 12 demonstrates the variation in the alloy grain size as a function of the added $\mathrm{B}$ and pouring temperature. It is evident that addition of $200 \mathrm{ppm} \mathrm{B}$ to the melt at $750^{\circ} \mathrm{C}$ is sufficient to produce finer grains $(\sim 250 \mu \mathrm{m})$ than those obtained from using the Al-10\%Ti master alloy $(\sim 850 \mu \mathrm{m})$ or
TABLE 3: WDS analysis (at.\%) of $\mathrm{AlB}_{2}$ and $\mathrm{AlB}_{12}$ phases observed in Figure 13(a).

\begin{tabular}{lc}
\hline $\mathrm{Al}$ & $\mathrm{B}$ \\
\hline 34.15 & 63.19 \\
35.40 & 64.47 \\
31.47 & 66.64 \\
33.62 & 65.51 \\
7.32 & 91.56 \\
8.52 & 90.78 \\
\hline
\end{tabular}

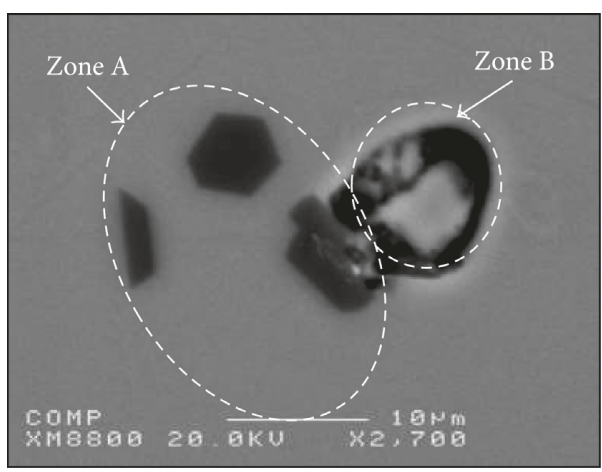

FIgUre 14: Presence of B and $\mathrm{Si}$ in Al-7\%Si alloy treated with $800 \mathrm{ppm} \mathrm{B}$. Note the geometric shape of the particles in Zone A.

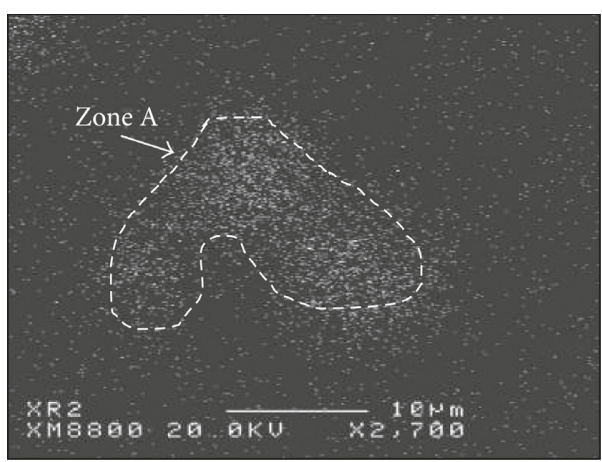

(a)

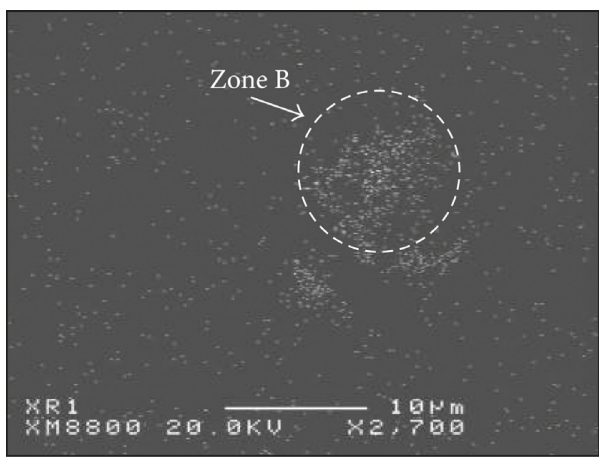

(b)

FIgUre 15: Distribution of (a) B and (b) Si in the $800 \mathrm{ppm}$ B-treated Al-7\%Si alloy shown in Figure 14.

the as-received alloy $(\sim 1854 \mu \mathrm{m})$ poured at $750^{\circ} \mathrm{C}$, as presented in Figure 4 . In this case, Figure 13 reveals the possibility of the coexistence of the two B-based compounds in 


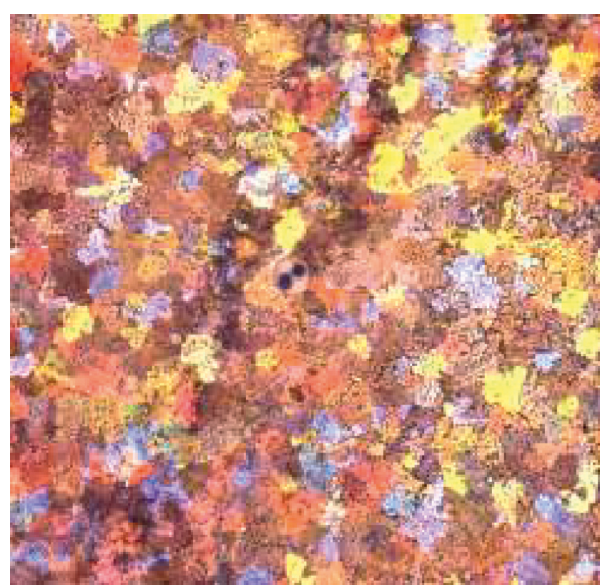

(a)

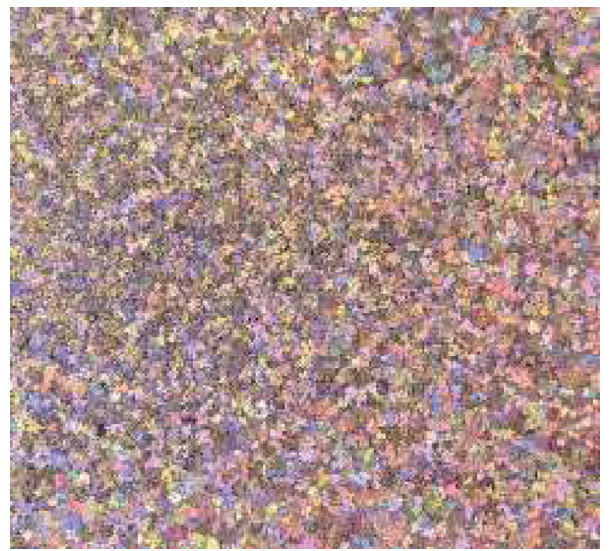

(c)

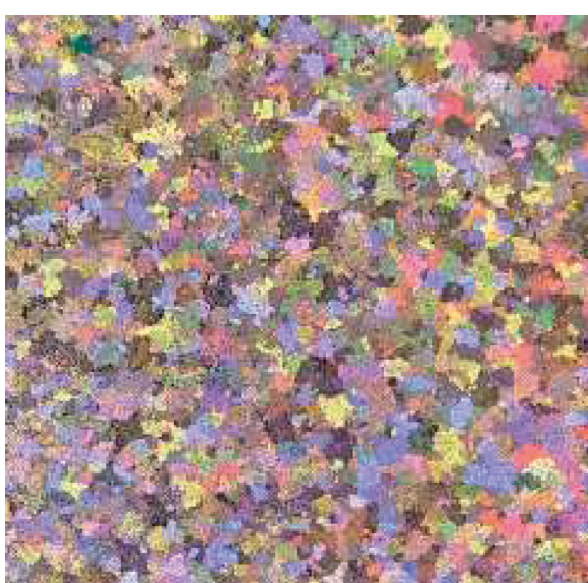

(b)

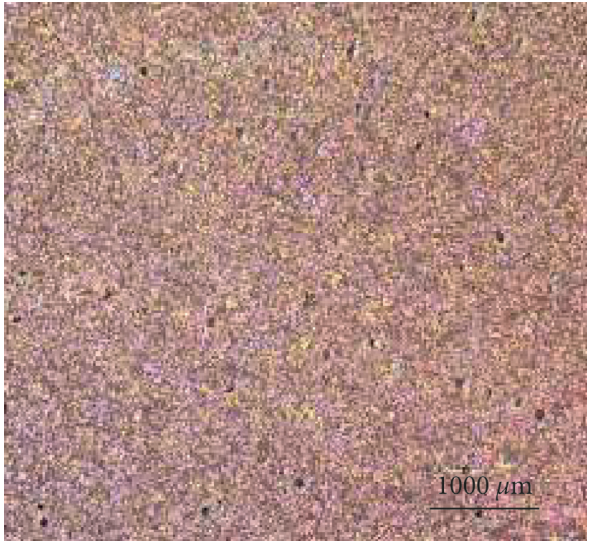

(d)

Figure 16: Evolution of the grain size in A356.2 alloy: (a) no addition, (b) Al-10\%Ti (0.2\%Ti), (c) Al-5\%Ti-1\%B (0.1\%Ti), and (d) Al-4\%B $\left(100 \mathrm{ppm}\right.$ B). Pouring temperature: $750^{\circ} \mathrm{C}$; stirring time: 30 minutes.

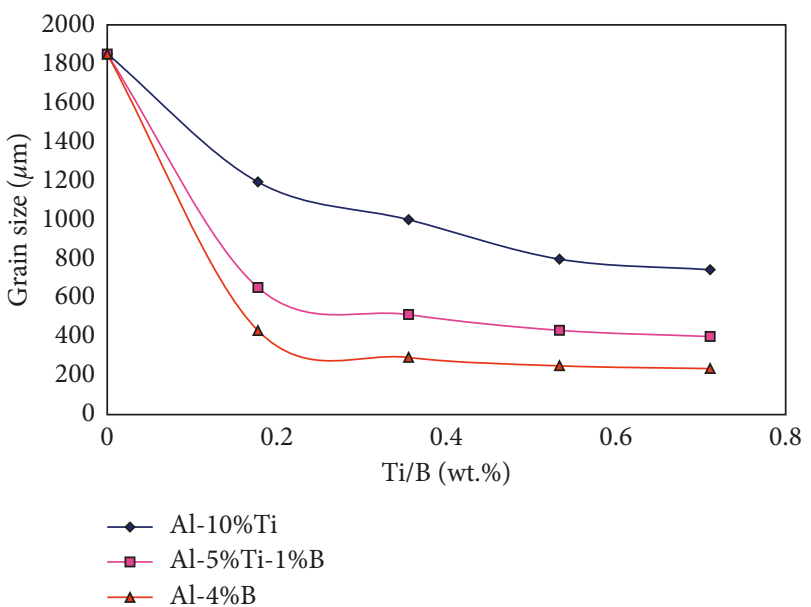

Figure 17: Comparison of the grain size observed in A356.2 alloy as a function of the type of the grain refiner added.

pure aluminum as confirmed by the associated WDS analysis (Table 3), whereas Figure 14 shows the distribution of $\mathrm{B}$ and $\mathrm{Si}$ phases in $\mathrm{Al}-7 \% \mathrm{Si}$ alloy. As can be seen, both elements precipitate away from each other (marked zones A and $\mathrm{B}$ ) in Figures 14 and 15. This observation is confirmed by the X-ray elemental distribution for each zone (Figure 16), indicating that there is no affinity for the reaction between these two elements. In contrast, when $\mathrm{Ti}$ was added with $\mathrm{B}$ (as $\mathrm{Al}-5 \% \mathrm{Ti}-1 \% \mathrm{~B}$ master alloy) to the 1050 commercial aluminum, a clear interaction between $\mathrm{Ti}$ and $\mathrm{B}$ took place, leading to the formation of $\mathrm{TiB}_{2}$. Thus, it could be concluded that $\mathrm{B}$ has no grain refining capacity when added to ultrapure aluminum, which is not the case when the metal contains traces of $\mathrm{Ti}$, leading to the possible formation of different nucleation sites that coexist, such as $\mathrm{AlB}_{12}, \mathrm{AlB}_{2}$, and $\mathrm{TiB}_{2}$ in Al-Si alloys. Evolution of the grain size of A356.2 alloy using different grain refiners is exhibited in Figure 16, whereas Figure 17 displays the variation in the grain size of A356.2 alloy as a function of the added type of the grain refiner.

\section{Conclusions}

Based on the obtained experimental results reported in this study, the following conclusions may be made:

(1) Addition of grain refiner master alloys in large amounts increases the nucleation temperature of the formation of $\alpha$-aluminum and eliminates the undercooling. 
(2) The Al-4\%B master alloy is more effective as a grain refiner compared to other types of master alloys. The presence of traces of $\mathrm{Ti}$ in the base A356.2 alloy would react with $\mathrm{B}$ leading to the formation of $\mathrm{TiB}_{2}$, which, in turn, would improve the effectiveness of the master alloy used.

(3) Since B has no affinity to react with $\mathrm{Si}$ in the base alloy, $\mathrm{AlB}_{2}$ particles are more effective as nucleation sites than the $\mathrm{Al}_{3} \mathrm{Ti}$ particles.

(4) Addition of a grain refiner also changes the morphology of the $\alpha$-Al dendrites from elongated to a rosette or more rounded form.

(5) Maintaining the liquid metal for a long period prior to pouring may lead to agglomeration of the intermetallic particles which would reduce the refining effectiveness of the master alloy used.

(6) Addition of $0.2 \mathrm{wt} . \% \mathrm{Ti}$ is sufficient to obtain good grain refining. Increasing the Ti content beyond that would lead to more precipitation of intermetallics with no further improvement in grain refining.

\section{Conflicts of Interest}

The authors declare they have no conflicts of interest.

\section{Acknowledgments}

The authors would like to thank Amal Samuel and Hicham Farid for enhancing the quality of the figures and images presented in this article.

\section{References}

[1] A. M. Samuel, H. W. Doty, S. Valtierra, and F. H. Samuel, "A metallographic study of grain refining of Sr-modified 356 alloy," International Journal of Metalcasting, vol. 11, no. 2, pp. 305-320, 2016.

[2] A. M. Samuel, H. W. Doty, S. Valtierra, and F. H. Samuel, "Effect of grain refining and Sr-modification interactions on the impact toughness of Al-Si-Mg cast alloys," Materials \& Design, vol. 56, pp. 264-273, 2014.

[3] G. K. Sigworth and T. A. Kuhn, "Grain refinement of aluminum casting alloys," International Journal of Metalcasting, vol. 1, no. 1, pp. 31-40, 2007.

[4] G. K. Sigworth, "Understanding quality in aluminum castings," International Journal of Metalcasting, vol. 5, no. 1, pp. 7-22, 2011.

[5] M. Easton and D. StJohn, "Grain refinement of aluminum alloys: Part II. Confirmation of, and a mechanism for, the solute paradigm," Metallurgical and Materials Transactions A, vol. 30, no. 6, pp. 1625-1633, 1999.

[6] P. Rogl and J. C. Schuster, Phase Diagrams of Ternary Boron Nitride and Silicon Nitride System, ASM International, Materials Park, OH, USA, 1992.

[7] L. F. Mondolfo, S. Farooq, and C. Tse, "Grain refinement of aluminium alloys by titanium and boron," in Proceedings of the Third International Conference on Solidification Processing 1987, The Institute of Metals, Sheffield, UK, pp. 133-136, September 1987.
[8] G. K. Sigworth, "Fundamentals of solidification in aluminum castings," International Journal of Metalcasting, vol. 8, no. 1, pp. 7-20, 2014.

[9] L. Bäckerud, P. Gustafson, and M. Johnsson, "Grain refining mechanisms in aluminum as a result of additions of titanium and boron, part II,” Aluminium, vol. 67, pp. 910-915, 1991.

[10] I. G. Davies, J. M. Dennis, and A. Hellawell, "The nucleation of aluminum grains in alloys of aluminum with titanium and boron," Metallurgical Transactions, vol. 1, pp. 275-279, 1970.

[11] I. Maxwell and A. Hellawell, "A simple model for grain refinement during solidification," Acta Metallurgica, vol. 23, no. 2, pp. 229-237, 1975.

[12] L. Arnberg, L. Bäckerud, and H. Klang, "Intermetallic particles in Al-Ti-B-type master alloys for grain refinement of aluminium," Metals Technology, vol. 9, no. 1, pp. 7-13, 1982.

[13] F. A. Crossley and L. F. Mondolfo, "Mechanism of grain refinement in aluminum alloys," JOM, vol. 3, no. 12, pp. 11431148, 1951.

[14] A. A. R. Abdel-Hamid and F. Durand, "Discussion of "the grain refining of aluminium and phase relationship in the Al-Ti-B system"," Metallurgical Transactions A, vol. 17, no. 2, p. 349, 1986.

[15] N. J. Finch, "The mutual solubility of titanium and boron in pure aluminium," Metallurgical Transactions, vol. 3, no. 10, pp. 2709-2711, 1972.

[16] P. S. Mohanty, F. H. Samuel, and J. E. Gruzleski, "Experimental study on pore nucleation by inclusions in aluminum castings," American Foundrymen's Society, vol. 99, pp. 555564, 1995.

[17] P. S. Mohanty, F. H. Samuel, and J. E. Gruzleski, "Studies on addition of inclusions to molten aluminum using a novel technique," Metallurgical and Materials Transactions B, vol. 26, no. 1, pp. 103-109, 1995.

[18] P. S. Mohanty, F. H. Samuel, J. E. Gruzleski, and T. J. Kosto, "Studies on the mechanism of grain-efinement in aluminium", in Proceedings of the Technical Sessions Presented by the TMS Light Metals Committee at the 123rd TMS Annual Meeting on Light Metals 1994, U. Mannweiler, Ed., pp. 1039-1045, San Francisco, CA, USA, February-March 1994.

[19] P. S. Mohanty, F. H. Samuel, and J. E. Gruzleski, "Mechanism of heterogeneous nucleation of pores in metals and alloys," Metallurgical Transactions A, vol. 24, no. 8, pp. 1845-1856, 1993.

[20] G. P. Jones and J. Pearson, "Factors affecting the grainrefinement of aluminum using titanium and boron additives," Metallurgical Transactions B, vol. 7, no. 2, pp. 223-234, 1976.

[21] P. Schumacher and A. L. Greer, "Studies of the action of grainrefining particles in aluminium alloys," in Essential Readings in Light Metals, John Wiley \& Sons, Inc., Hoboken, NJ, USA, pp. 366-374, 2013.

[22] P. Schumacher and A. L. Greer, "Devitrification of the stable Al-rich amorphous alloy $\mathrm{Al}_{85} \mathrm{Y}_{8} \mathrm{Ni}_{5} \mathrm{Co}_{2}$," Key Engineering Materials, vol. 81-83, pp. 631-636, 1993.

[23] M. A. Kearns, S. R. Thistlethwaite, and P. S. Cooper, "Recent advances in understanding the mechanism of aluminium grain refinement by TiBAl master alloys," in Light Metals 1996, W. Hale, Ed., pp. 713-720, TMS, Warrendale, PA, USA, 1996.

[24] W. Stiller and T. Ingenlath, "Industrial boron treatment of aluminium conductor alloys and its influence on grain refinement and electrical conductivity," Aluminium, vol. 60, pp. E577-E580, 1984. 
[25] P. S. Cooper and M. A. Kearns, "Removal of transition metal impurities in aluminium melts by boron additives," Materials Science Forum, vol. 217-222, pp. 141-146, 1996.

[26] G. Q. Wang, S. H. Liu, C. M. Li, and Q. Gao, "Reaction of boron to transition metal impurities and its effect on conductivity of aluminum," Transactions of Nonferrous Metals Society of China, vol. 12, no. 6, pp. 1112-1116, 2002.

[27] H. D. Alamidari, D. Dube, and P. Tessier, "Behavior of boron in molten aluminum and its grain refinement mechanism," Metallurgical and Materials Transactions A, vol. 44, no. 1, pp. 388-394, 2013.

[28] L. F. Mondolfo, Aluminum Alloy Structure, and Properties, Butterworth, London, UK, 1976.

[29] G. K. Sigworth, "The grain refining of aluminum and phase relationships in the Al-Ti-B system," Metallurgical Transactions $A$, vol. 15, no. 2, pp. 277-282, 1984.

[30] A. A. Giardini, J. A. Kohn, L. Toman, and D. W. Eckart, Boron-Synthesis, Structure and Properties, Plenum Press, New York, NY, USA, 1960.

[31] W. V. Youdelis and C. S. Yang, "Ti( $(\mathrm{Al}, \mathrm{Si})_{3}$ compound formation in non-equilibrated Al-Ti-Si," Metal Science, vol. 14, no. 10, pp. 500-501, 1980.

[32] S. Gagné, Effets de L'augmentation de la Teneur en Titane Sur L'affinage des Grains de L'alliage A356.2, M.Sc. thesis, Université du Québec à Chicoutimi, Saguenay, QC, Canada, 2005.

[33] S. A. Kori, B. S. Murty, and M. Chakraborty, "Development of an efficient grain refiner for Al-7Si alloy and its modification with strontium," Materials Science and Engineering A, vol. 283, no. 1-2, pp. 94-104, 2000.

[34] S. Nafisi and R. Ghomashchi, "Boron-based refiners: implications in conventional casting of $\mathrm{Al}-\mathrm{Si}$ alloys," Materials Science and Engineering A, vol. 452-453, pp. 445-453, 2007.

[35] L. Bäckerud, G. Chai, and J. Tamminen, Solidification Characteristics of Aluminum Alloys, Vol. 2, Foundry Alloys, American Foundry Society Inc., Des Plaines, IL, USA, 1990.

[36] S. Nafisi and R. Ghomashchi, "Grain refining of conventional and semi-solid A356 Al-Si alloy," Journal of Materials Processing Technology, vol. 174, no. 1-3, pp. 371-383, 2006. 


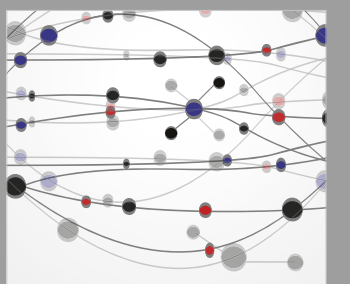

The Scientific World Journal
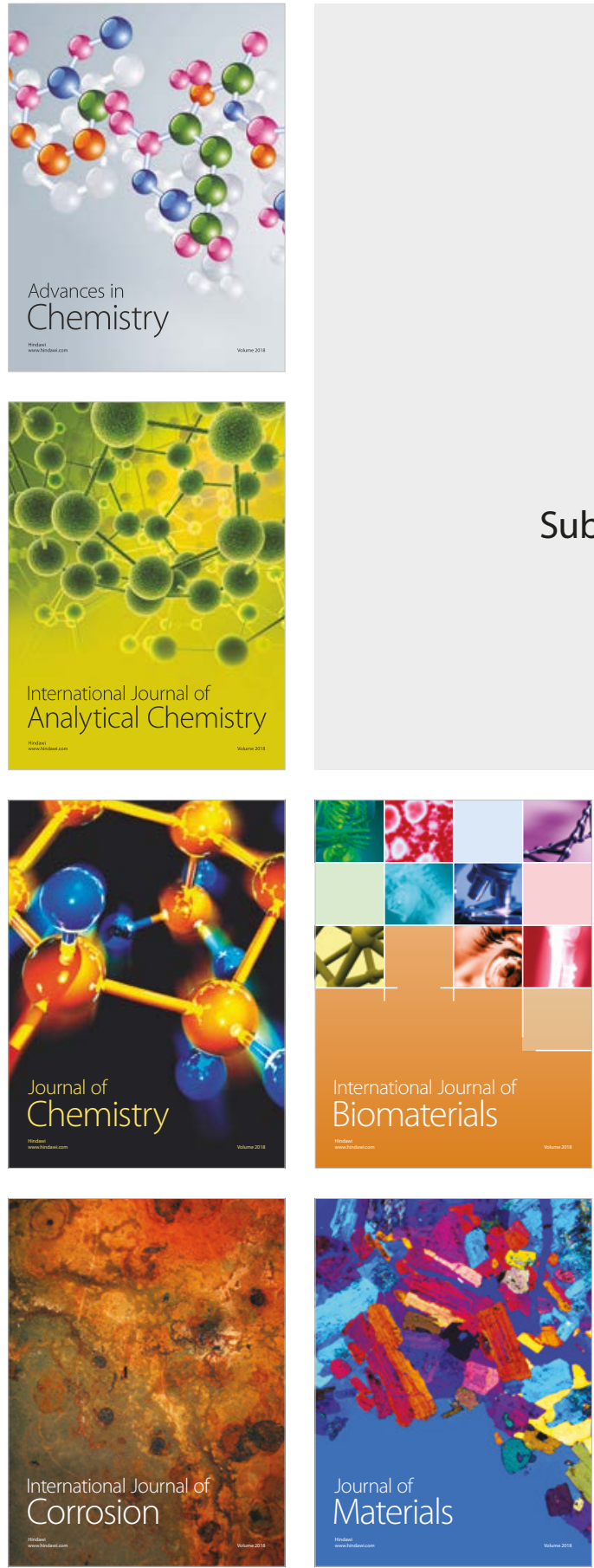

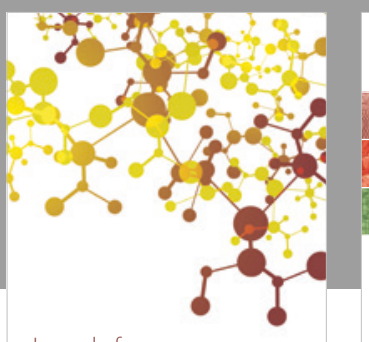

Journal of

Applied Chemistry
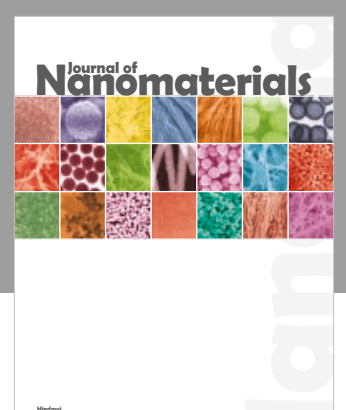

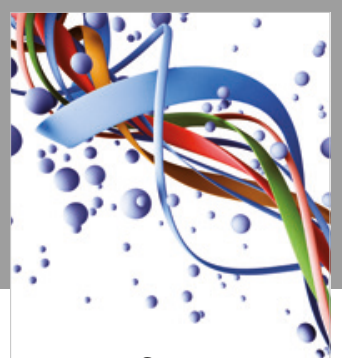

Scientifica

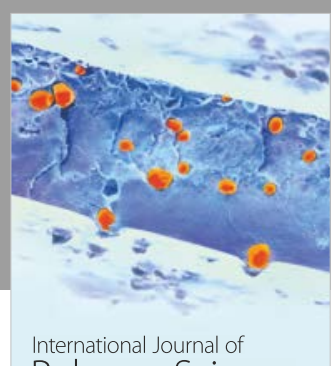

Polymer Science

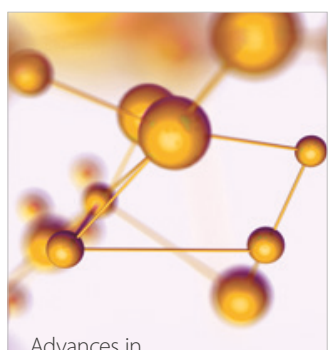

Physical Chemistry
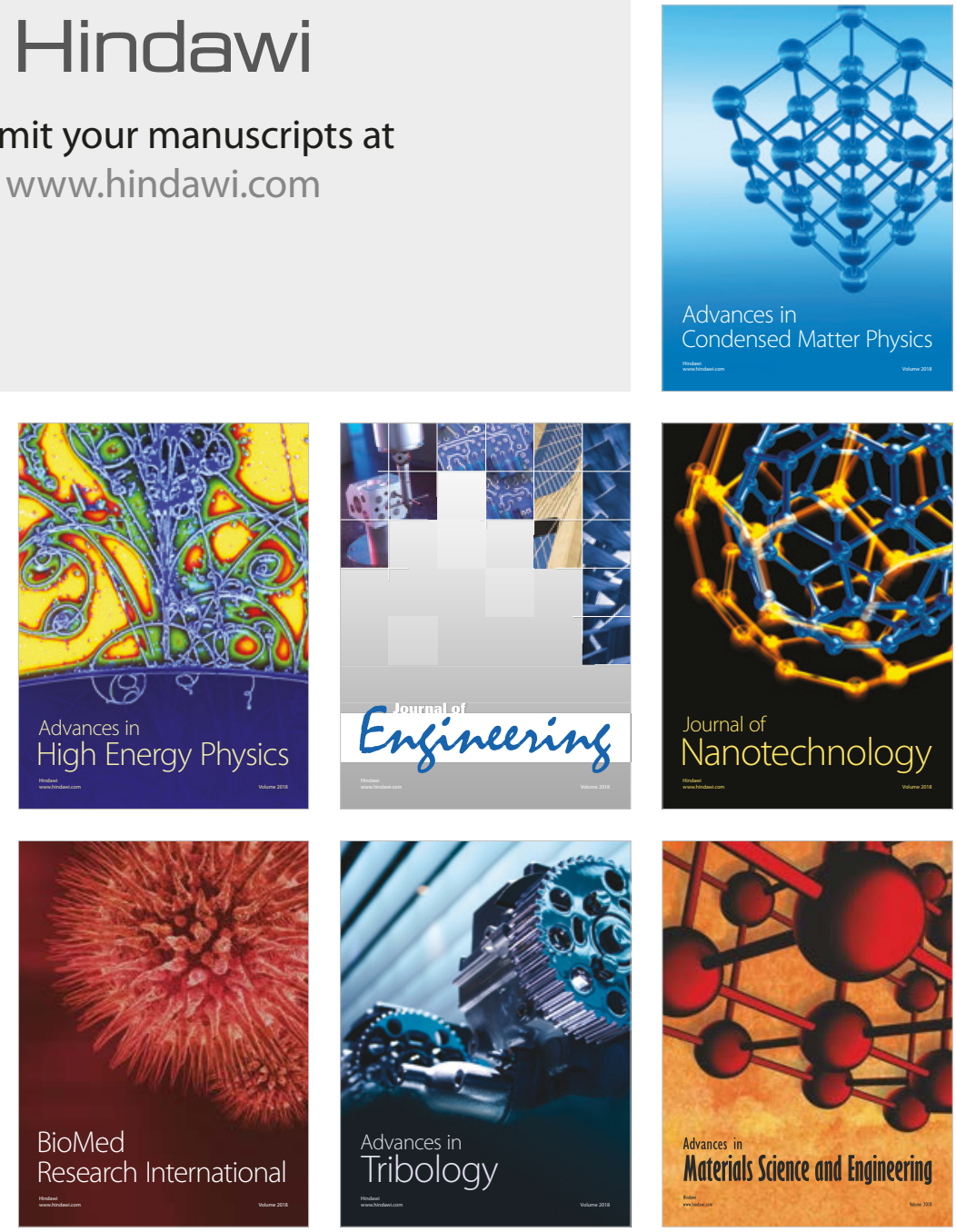